BENTUK PERTUNJUKAN GURITAN PADA TRADISI PERNIKAHAN DI KOTA PAGARALAM

DedyFirduansyah, AbiKaroma Batubara

EKSISTENSI MUSIK KOLINTANG KAYU DALAM KEHIDUPAN PIKPP DI PT.PURSI PALEMBANG SUMATERA SELATAN

RIO EKA PUTRA

ESTETIKA TARI MELAJU DENGAN MUTU

Rully Rochayati, Treny Hera

KAJIAN SOSIOLOGI TARI KEBAGH DI MASYARAKAT DESA PENGANDONANKOTA PAGAR ALAMRANI CHINTIA SARI

KONTRIBUSI GURU SENI BUDAYA DALAM PENGEMBANGAN KREATIFITAS SISWA PADA PEMBELAJARAN SENI TARI

Naomi Diah Budi Setyaningrum

45

PENERAPAN METODE RESITASI DALAM PEMBELAJARAN NOTASI TARI PADA PROGRAM STUDI PENDIDIKAN SENDRATASIK UNIVERSITAS PGRI PALEMBANG

EfitaElvandari

PENGARUH METODE KERJA KELOMPOK PADA HASIL PEMBELAJARAN TARI TOPENG IRENG DI KELAS VIII SMP NEGERI 15 PALEMBANG

NEMI KAROLINA

PENGARUH MUSIK DANGDUTTERHADAP KECERDASAN EMOSI REMAJA SMPKELAS IX

NOVDALY FILLAMENTA

SITI RAFIAH SEBAGAI TOKOH PEREMPUAN PENGEMBAN PERISTIWA DALAM SYAIR ABDUL MULUK KARYA RAJA ALI HAJI

MOHAMMAD ARFANI

STRUKTUR KERUANGAN TARI REJANG RENTENG DALAM UPACARA PERSEMBAHYANGAN DI PURA PUSEH DESA KALIREJO KECAMATAN BELITANG II KABUPATEN OKU TIMUR

IWAYAN AYUNITA 


\title{
KONTRIBUSI GURU SENI BUDAYA DALAM PENGEMBANGAN KREATIFITAS SISWA PADA PEMBELAJARAN SENI TARI
}

\author{
Oleh: \\ Naomi Diah Budi Setyaningrum \\ (Dosen FKIP Program Studi Pendidikan Sendratasik Universitas PGRI Palembang)
}

\begin{abstract}
ABSTRAK
Tari merupakan bentuk aktifitas manusia, seharusnya dapat menjadi salah satu bentuk aktifitas yang dapat dilakukan oleh siswa dalam menyalurkan energinya, sehinga mereka dapat menumbuhkembangkan daya kreativitasnya melalui kegiatan seni tari. Hal tersebut sesuai dengan tujuan pendidikan tari yakni: Tujuan pendidikan tari adalah membina ekspresi artistiknya dengan baik serta dapat menumbuh kembangkan daya kreatifitasnya. Selain dapat menumbuh kembangkan kreatifitasnya dengan kegiatan seni tari diharapkan dapat memberikan pengalaman baru bagi siswa serta menjadi sarana perkembangan motoriknya secara utuh. Guru seni budaya memiliki tanggung jawab dalam proses pembelajaran, salah satunya seni tari, dan tanggung jawab bagaimana dapat memotivasi siswa dalam pembelajaran seni tari di sekolah, yang memiliki kontribusi terhadap perkembangan kreatifitas seni tari. Pembelajaran tari harus dirancang secara kreatif, yang memungkinkan terjadinya interaksi mandiri antara guru dan siswa.Dalam melahirkan suatu karya tari yang kreatif, maka diperlukan seorang guru (pendidik), yang memahami pembelajaran tari bagi kepentingan dunia pendidikan. $\mathrm{Hal}$ tersebut dikarenakan pengajaran sebagai ujung tombak dari dari penyampaian kurikulum pengajaran yang akan diberikan guru pada siswanya.
\end{abstract}

Kata Kunci: Kontribusi guru, pengembangan kreatifitas, seni tari.

\section{A. PENDAHULUAN}

Pembelajaran tari tradisional dewasa ini ada kecenderungan diberikan melalui polapola baku yang sudah ada, sehingga siswa (peserta didik) hanya meniru apa yang diajarkan oleh guru tanpa sedikitpun siswa mengeluarkan ide/gagasan kreatifnya. Hal ini menjadikan peserta didik cenderung pasif dan tidak kreatif.Tari yang merupakan bentuk aktifitas manusia, seharusnya dapat menjadi salah satu bentuk aktifitas yang dapat dilakukan oleh siswa dalam menyalurkan energinya, sehinga mereka dapat menumbuh kembangkan daya kreativitasnya melalui kegiatan seni tari. Hal tersebut sesuai dengan tujuan pendidikan tari yakni: Tujuan pendidikan tari adalah membina ekspresi artistiknya dengan baik serta dapat menumbuh kembangkan daya kreatifitasnya. Selain dapat menumbuh kembangkan kreatifitasnya dengan kegiatan seni tari diharapkan dapat memberikan pengalaman baru bagi siswa serta menjadi sarana perkembangan motoriknya secara utuh.

"Eksplorasi merupakan suatu persyaratan yang penting, hal ini dapat diwujudkan dengan adanya komunikasi yang aman antara guru dan siswa, kenyamanan psikologis siswa juga penting untuk menumbuhkan tindakan kreatif". Adapun pendapat yang lainnya mengungkapkan bahwa:" Pada proses pembelajaran tari kreatif, 
aspek kreativitas memiliki pengaruh yang besar dalam terciptanya suatu karya, ditunjang oleh aspek-aspek perkembangan lain yang sejalan dengan karakteristik yang dimiliki siswa. Tari kreatif membantu perkembangan kognitif, afektif, fisik, dan sosial .

Guru seni budaya memiliki tanggung jawab dalam proses pembelajaran, salah satunya seni tari, dan tanggung jawab bagaimana dapat memotivasi siswa dalam pembelajaran seni tari di sekolah, yang memiliki kontribusi terhadap perkembangan kreatifitas seni tari. Pembelajaran tari harus dirancang secara kreatif, yang memungkinkan terjadinya interaksi mandiri antara guru dan siswa.Dalam pembelajaran seni tari dapat dilaksanakan secara kelompok untuk menumbuhkan jiwa kerjasama dan efisien.

Manusia dalam semua aktifitasnya selalu dikendalikan oleh otak.Sebagai makluk sosial manusia memiliki pikiran dan imajinasi yang luar biasa.Pikiran digunakan sebagai penggerak keinginan dan imajinasi digunakan sebagai daya pikir dalam menelaah sesuatu yang bersifat lebih unik bahkan bersifat aneh.Pikiran dan imajinasi merupakan dasar manusia untuk berkreatifitas.

Kreatifitas merupakan salah satu yang dimiliki oleh setiap manusia yang bersifat baru, bermanfaat dan dapat dimengerti, baru berarti inovatif, belum pernah ada sebelumnya, bersifat unik dan menarik.Bermanfaat artinya memiliki daya guna.Munandar (2012:25) menjelaskan "Kreatifitas sebagai kemampuan umum untuk memberikan gagasan-gagasan baru yang diterapkan dalam pemecahan masalah, atau sebagi kemampuan untuk melihat hubungan-hubungan baru antara unsur-unsur yang ada sebelumnya".Ditinjau dari sisi kteatifitas, sebenarnya setiap orang memilikinya.Hal yang membedakan manusia satu dengan manusia yang lainnya dari sisi kreatifitas adalah dikembangkan atau tidaknya. Contoh sederhana bahwa suatu aktifitas disebut sebagai tontonan apabila ia dilakukan dengan kesengajaan dengan maksut untuk dilihat oleh orang lain untuk ditonton. Aktifitas baru yang muncul dari diri manusia yang memiliki tujuan dan punya motifasi dalam mewujidkan kreatifitas yang dimilikinya.

Kreativitas merupakan bagian dari emosi dan rasa ingin terampil dalam jiwa terhadap sesuatu atas tantangan yang penuh dengan gagasan baru.Jika ditinjau dari sisi kreatifitas sebenarnya setiap orang memilikinya.Hal yang membedakan manusia yang satu dengan yang lainnya adalah dari sisi kreatifitas adalah dikembangkan atau tidaknya.

\section{B. METODE PENELITIAN}

Metode penelitian adalah cara-cara yang mengatur prosedur penelitian ilmiah pada umumnya.Metode dalam penelitian ini menggunakan metode deskriptif kualitatif, metode deskriptif adalah suatu metode dalam pencarian fakta status kelompok manusia, suatu objek, suatu kondisi, suatu sistem pemikiran ataupun suatu peristiwa pada masa sekarang dengan interpretasi 
yang tepat (Sedarmayanti, dkk, 2002:33).Penelitian Kualitatif tidak semata-mata mendeskripsikan, tetapi yang lebih penting, menemukan makna yang terkandung dibaliknya, sebagai makna tersembunyi atau dengan sengaja disembunyikan (Ratna, 2010: 94).Menurut Bogdan dan Taylor (dalam Ratna, 2010:94), kualitatif adalah metode yang pada gilirannya menghasilkan data deskriptif dalam bentuk kata-kata, baik tertulis maupun lisan.Melalui pendekatan kualiltatif, penelitian ini bertujuan untuk mengungkap makna dibalik fenomena/gejala yang sedang diteliti, tanpa merubah objek penelitian baik sebelum atau sesudah diadakan penelitian.

\section{HASIL DAN PEMBAHASAN}

Kreatifitas merupakan salah satu yang dimiliki oleh setiap manusia yang bersifat baru, bermanfaat dan dapat dimengerti, baru berarti inovatif, belum pernah ada sebelumnya, bersifat unik dan menarik.Bermanfaat artinya memiliki daya guna.Munandar (2012:25) Menjelaskan "Kreatifitas sebagai kemampuan umum untuk memberikan gagasan-gagasan baru yang diterapkan dalam pemecahan masalah, atau sebagi kemampuan untuk melihat hubungan-hubungan baru antara unsur-unsur yang ada sebelumnya".Ditinjau dari sisi kteatifitas, sebenarnya setiap orang memilikinya.Hal yang membedakan manusia satu dengan manusia yang lainnya dari sisi kreatifitas adalah dikembangkan atau tidaknya. Contoh sederhana bahwa suatu aktifitas disebut sebagai tontonan apabila ia dilakukan dengan kesengajaan dengan maksut untuk dilihat oleh orang lain untuk ditonton. Aktifitas baru yang muncul dari diri manusia yang memiliki tujuan dan punya motifasi dalam mewujidkan kreatifitas yang dimilikinya.

Ciri-ciri manusia kreatif menurut pendapat Guilford dalam menjelaskan ciri-ciri manusia kreatif:

a. Fluency; kesigapan, kelancaran, kemampuan untuk menghasilkan banyak gagasan.

b. Fleksibilitas; kemampuan untuk menggunakan bermacam-macam pendekatan dalam mengatasi persoalan.

c. Originalitas; kemampuan untuk mencetuskan gagasan-gagasan asli.

d. Elaborasi; kemampuan untuk melakukan hal-hal secara detail terperinci.

e. Redifination; kemampuan untuk merumuskan batasan-batasan dengan melihat dari sudut lain daripada caracara yang lazim.

Berdasarkan tinjauan di atas mengenai kreatifitas maka dapat disimpulkan bahwa kreativitas merupakan bagian dari emosi dan rasa ingin terampil dalam jiwa terhadap sesuatu atas tantangan yang penuh dengan gagasan baru.Jika ditinjau dari sisi kreatifitas sebenarnya setiap orang memilikinya. Hal yang membedakan manusia yang satu dengan yang lainnya adalah dari sisi kreatifitas adalah dikembangkan atau tidaknya dalam melahirkan suatu karya tari yang kreatif, maka diperlukan seorang guru (pendidik), yang 
memahami pembelajaran taribagi

kepentingan dunia pendidikan

Hal tersebut dikarenakan pengajaran sebagai ujung tombak dari dari penyampaian kurikulum pengajaran yang akan diberikan guru pada siswanya. Selain hal tersebut seorang guru tari juga harus memahami filosofis mengajar, kurikulum yang dikembangkan, materi pembelajaran, metode serta strategi, evaluasi dan sumber belajar yang dipergunakan oleh guru tari dalam yang berfungsi pula dalam mengembangkan berbagai kecerdasan juga kemampuan siswa (Menstimulus kecerdasan majemuk siswa).

Sifat dasar seni adalah kreatif, artistik, memiliki nilai humanis, sosial, religius, individual. Agar tercapainya dasar pemikiran di atas maka kompetensi dasar di dalam pembelajaran seni tari lebih ditekankan (difokuskan), pada pengalaman eksplorasi untuk melatih kemampuan sensorik dan motoriknya. Dalam pelaksanaan pembelajaran seni tari perlu alat pendukung atau media sebagai alat bantu siswa dalam belajar. Dengan media audio visual sorang guru dapat memperlihatkan beberapa bentuk bentuk pertunjukan tari baik tarian tradisi, kontemporer, kreasi juga tari-tari modern yang ada. Fungsinya adalah agar siswa bisa mengapresiasi beberapa karya tari yang ada, dengan harapan akan memberikan motifasi kepada mereka untuk mencintai karya-karya yang ada sebagai bentuk budaya yang dimiliki bangsa ini, yang memiliki keindahan dan nilai- nilai humanis yang harus dipelajari dan dikembangkan.

Selain hal tersebut di atas seorang guru seni budaya juga mengajarkan pada siswanya bagaimana mengeksplorasi gerak sebagai media dari tari untuk mengolahnya. Melalui media tubuhnya siswa akan mendapat kepuasan dalam proses perkembangan fisik dan jiwa sebagai eksistensi dirinya dalam bersosialisasi. Sedangkan melalui berlatih menguasai gerak ataupun menyusun motifmotif gerak yang disesuaikan dengan tema tarinya melalui proses pengamatan, pengalaman, dan juga penghayatan. Seorang guru harus mampu mengembangkan potensi siswanya, menstimulus siswanya agar dapat menuangkan ide gagasannya dan mengembangkannya dalam ekspresi gerak yang kreatif.Ide gagasan sebisa mungkin orisinil. Sebagai contoh ide gerak tentang binatang Kupu-kupu, dimana siswa diajak melihat, mengamati gerak dan keindahan kupukupu; saat terbang dari satu bunga ke bunga lain; saat kupu-kupu menghisap madu; saat kupu-kupu bekejaran dengan kupu-kupu yang lainnya. Kemudian siswa diajak untuk mengeksplorasi dalam bentuk reportuarreportuar gerak tari.Guru juga sebagai fasilitator, seharusnya membiarkan siswanya memvisualisasikan semua gerak yang diinginkannya dan selanjutnya guru dapat memilih gerak yang penting dan tidak serta memberi masukan tentang hal-hal yang perlu dikembangkan dan dibenahi sehingga siswa 
mampu menyusun suatu karya tari yang artistik.

Kreatifitas seni sangat penting dalam proses pembelajaran seni, melalui imajinasinya siswa diajak untuk mengeksplorasi dan menuangkan gagasannya. Dalam proses ini siswa harus dalam suasana gembira dan bukan sebaliknya, sehingga dengan suasana batin yang ada akan menghasilkan karya-karya yang penuh warna dan mampu mencapai kreatifitas yang diharapkan. Siswa mampu menuangkan gagasannya dalam reportoar tari yang dapat mewadahi ide gagasannya dan menyampaikan nilai-nilai yang ingin disampaikan akan sampai kepada penonton (penghayat seni).

\section{Proses Pembelajaran Tari Kreatif}

Pembelajaran adalah proses interaksi peserta didik dengan pendidik dan sumber belajar pada suatu lingkungan belajar. Pembelajaran merupakan bantuan yang diberikan pendidik agar dapat terjadi proses pemerolehan ilmu dan pengetahuan, penguasaan kemahiran dan tabiat, serta pembentukan sikap dan kepercayaan pada peserta didik. Pembelajaran lebih menekankan pada cara-cara untuk mencapai tujuan dan berkaitan dengan bagaimana cara mengorganisasikan materi pelajaran, menyampaikan mata pelajaran, dan mengelola pelajaran. Pembelajaran adalah suatu kombinasi yang tersusun meliputi unsur-unsur manusiawi, material, fasilitas perlengkapan dan prosedur yang saling mempengaruhi dalam mencapai pembelajaran (Hamalik, 2009:57).

Dapat disimpulkan pembelajaran dapat diartikan suatu aktifitas yang dengan sengaja untuk memodifikasi berbagai kondisi yang diarahkan untuk tercapainya suatu tujuan yaitu tujuan kurikulum.Karena pembelajaran adalah suatu usaha yang disengaja melibatkan dan menggunakan pengetahuan profesional yang dimiliki guru untuk mencapai tujuan kurikulum.

Tari merupakan bahasa komunikasi manusia yang diungkapkan melalui gerak ritmis dan indah.Gerak tari bukanlah gerak keseharian, tetapi gerak yang telah mengalami stilisasi, sehingga menimbulkan kesan estetis. Guru harus dapat menciptakan suasana belajar yang menyenangkan, sehingga siswa dapat bebas bergerak tanpa suatu tekanan, bergerak sesuai dengan situasi batinnya. Kreatifitas adalah kemampuan seseorang untuk menghasilkan komposisi produk atau gagasan apa saja yang pada dasarnya baru dan sebelumnya tidak dikenal. Hal yang penting dalam mewujudkan kreatifitas anak adalah sorang guru harus dapat memberikan kebebasan kepada siswa untuk dapat bereksperimen/melakukan eksperimen dalam rangka mewujudkan atau mengekpresikan dirinya secara kreatif.Maka seorang guru dituntut juga untuk menyediakan sarana dan prasarana yang dibutuhkan/diperlukan.

Dalam proses berkarya seni guru diharapkan dapat membimbing siswa dalam 
mengungkapkan cara bergerak mereka yang masing-masing pribadi pasti memiliki keunikan tersendiri dan bergerak sesuai dengan perasaannya. Adapun bentuk proses latihan tarinya adalah sebagai berikut:

1. Latihan mempersiapkan tubuh sebagai alat ekspresi (medium tari adalah gerak tubuh manusia.

2. Latihan gerak kepala, tangan, gerak badan, gerak kaki untuk menumbuhkan kesadaran kepada peserta didik bahwa seluruh anggota badan merupakan sumber gerak tari.

3. Latihan bergerak dengan ritme untuk tujuan memperkenalkan dan membiasakan siswa menanggapi irama, tempo dan frase dalam musik sebagai iringan tarinya.

4. Bergerak dengan arah hadap, hal tersebut untuk membiasakan siswa dapat cepat menyesuaikan dengan tempat di mana ia menari.

5. Latihan bergerak dengan membentuk formasi ataupun pola lantai (komposisi), tujuannya adalah untuk melatih konsentrasi, serta dapat cepat menyesuaikan dengan tempat menari dan melatih kemampuan bekerja sama dalam kelompok garapan tari.

\section{Pendekatan Kreatif Dalam Berolah Seni Tari}

Pendekatan kreatifitas dalam berolah seni tari sangat penting dilakukan. Proses kreatifitas tidak dapat dilakukan secara tiba-tiba (sekonyong-konyong)/instan. Pemunculan suatu kreatifitas diperlukan sebuah proses melalui pemberian kesempatan untuk menjelajah ruang-ruang gerak secara kreatif dan penuh imajinatif. Dalam hal ini kreatifitas siswa sebagai proses yang diutamakan dalam kegiatan berkarya seni tari dan jangan terlalu cepat menuntut produk kreatif seni mereka bermakna dan bermanfaat, karena produk seni yang tinggi, bukanlah hal yang instan akan tetapi melalui proses yang panjang. Kreatif adalah pemberian kebebasan kepada siswa untuk mengekspresikan dirinya di dalam memunculkan ide/ atau gagasannya dalam repertoar gerak, yang dinamis dan penuh imajinatif, sehingga dengan harapan nantinya akan menghasilkan bentuk tari kreatif. Untuk mewujudkan hal tersebut di atas maka diperlukan latihan yang memiliki intensitas tinggi.

Output kreatifitas akan lebih berkembang jika guru dapat merangsang siswa untuk ikut melibatkan dirinya dalam kegiatan eksplorasi, serta memberikan motifasi kepada siswanya untuk menciptakan gerak-gerak kreatif. Gerak yang sesuai dengan ide garap dan mempunyai kekhasan tersendiri (ciri khas). Adapun treatment penciptaan tari kreatif menurut pendapat Smith (1989:20), adalah:

Ada beberapa rangsangan yang dapat memotifasi siswa bergerak kreatif yaitu: rangsang auditif, visual, kinestik, gagasan dan peraba. Rangsang auditif meliputi berbagai 
suara bunyi-bunyian seperti suara manusia, suara binatang, suara alat musik atau instrumentalia, suara yang ditimbulkan oleh alam seperti suara angin, suara desiran ombak di pantai, suara air yang menetes, suara daundaun yang berguguran diterpa oleh angin dan lain sebagainya.

\section{Lingkungan Sosial Dan Alam Sebagai Salah Satu Sumber Belajar Seni Tari}

Pembelajaran tari hendaknya memberdayakan lingkungan dan alam sebagai sumber belajar, artinya banyak ide gagasan/tema dalam tari diambil dari lingkungan sosial dan alam. Lingkungan sosial pengertiannya adalah hal-hal kejadian di kehidupan sosial anak dapatlah menjadi ide segar di dalam mengangkat sebuah tema tari, kejadian-kejadian disekelilingnya, latar belakang budayanya yang masing-masing memiliki kearifan tersendiri. Contohnya: kehidupan anak-anak di tepian sungai Musi di Kota Palembang, dimana masyarakatnya memanfatkan sungai sebagai tempat untuk mata pencahariannya. Dengan lingkungan sosial yang ada maka anak bisa menciptakan tari dengan tema tari Nelayan, Tari Dayung, Tari Sampan, Tari mencari ikan dan lain sebagainya. Disamping itu anak-anak yang dibesarkan di lingkungan pertanian akan memiliki ide gagasan yang berbeda dengan kehidupan anak-anak yang dibesarkan di tepian sungai. Barangkali mereka akan mengusung kehidupan pertanian di desa, serta menghasilkan karya tari dengan judul: Tari Tani, Pesta panen dan lain sebagainya.

Seorang kritikus seni dari Amerika Serikat (USA), yaitu Jhon Martin, dalam bukunya yang berjudul "The Modern Dance", mengemukakan bahwa "gerak adalah pengalaman fisik yang paling elementer dari kehidupan manusia (Soedarsono 1987:81). Landasan elemen dasar tari adalah gerak, gerak yang dimaksud adalah gerak yang disesuaikan dengan apa yang ingin diungkapkannya sehingga karya yang dihasilkan dapat dinikmati dengan rasa oleh penonton dan penghayat. Senada dengan pendapat Jhon Martin, Susane K Langer dalam bukunya yang berjudul "Problem of Art", mengemukakan bahwa gerak-gerak ekspresi adalah gerak-gerak yang indah, yang dapat menggetarkan perasaan manusia, sedangkan gerak yang indah adalah gerak yang distilir dan mengandung ritme tertentu. Kata indah identik dengan bagus, yang dapat memuaskan perasaan batin manusia (Soedarsono 1987:82).

Hal yang sering dilupakan oleh seorang guru adalah: Bahwa setiap anak dengan adanya latar belakang yang berbeda, mereka secara individu memiliki keunikan tersendiri. Begitu juga di dalam menuangkan gagasannya lewat gerak, mereka memiliki cara tersendiri dalam bereksplorasi, satu dan yang lainnya tentu saja tidak sama. Hal tersebut dikarenakan dalam menyerap informasi mereka satu sama lainnya berbeda. Kemampuan 
dalam belajar dipengaruhi juga oleh gaya belajarnya.

Seharusnya seorang seorang guru dapat membangun proses belajar anak melalui aktifitas anak secara optimal. Contohnya, dengan indra penglihatan, melalui indra penglihatan siswa bisa dibimbing untuk mengamati kehidupan disekelilingnya apa yang dia amati, mengamati keindahan alam sebagai karya cipta Tuhan yang luar biasa indahnya seperti kehidupan manusia, binatang, tumbuhtumbuhan, panorama pantai yang menawarkan sejuta keindahan dan lain sebagainya.

Kemudian tahap berikutnya siswa diajak menuangkan gagasannya dalam gerak, melalui eksplorasi, menjelajah ruang gerak tangan, kaki kepala, tubuh sehingga mereka mampu menghasilkan gerak yang orisinil gerak yang tidak meniru orang lain, gerak yang tercipta karena proses batin dalam berimajinasi. Melalui gerak yg ritmis yang mereka ciptakan akan lahir karya-karya tari kreatif.

\section{D.SIMPULAN}

Kreativitas adalah kemampuan untuk mencipta, kreatifitas dalam pendidikan tari adalah pengalaman mengekspresikan diri anak dalam mengeluarkan ide-ide kreatifnya melalui pembelajaran seni tari. Suatu pembelajaran yang berorientasi pada prinsip-prinsip perkembangan anak salah satunya adalah siswa dapat belajar dengan baik apabila kebutuhan fisiknya terpenuhi serta merasakan nyaman dalam proses pembelajaran, sehingga siswa mampu belajar serta menghasilkan karya-karya kreatif.

\section{DAFTAR PUSTAKA}

Hamalik, Oemar. 2009. Kurikulum dan Pembelajaran Berdasarkan Pendekatan Sistem . Jakarta: Bumi Aksara

Munandar, Utami. 2012. Pengembangan Kreatifitas Anak Berbakat, Jakarta : Rineke Cipta.

Ratna, Nyoman Kutha. 2010. Metodologi Penelitian Kajian Budaya dan IImu Sosial Humaniora Pada Umumnya. Yogyakarta: Pustaka Pelajar

Soedarsono. 1986. "Pengantar Pengetahuan Dan Komposisi Tari" dalam Pengetahuan Elementer Tari dan Beberapa Masalah Tari. Jakarta: Direktorat Kesenian Proyek Pengembangan Kesenian Jakarta.

Sardiman. 2010. Interaksi \& Motivasi Mengajar. Jakarta : PT. Raja Grafindo Persada.

Sedarmayanti dan Syarifudin Hidayat. 2002. Metodologi Penelitian. Bandung: Penerbit Mandar Maju. 
